\title{
Service quality in higher education: Applying HEdPERF scale in Vietnamese universities
}

\author{
Le Dinh Minh Tri ${ }^{1 *}$, Tran Thi Hoang Lam ${ }^{1}$, Nguyen Quang Trang ${ }^{1}$ \\ ${ }^{1}$ International University, Vietnam National University Ho Chi Minh City, Vietnam \\ *Corresponding author: ldmtri@hcmiu.edu.vn
}

\begin{tabular}{|c|c|}
\hline ARTICLE INFO & ABSTRACT \\
\hline $\begin{array}{l}\text { DOI: 10.46223/HCMCOUJS. } \\
\text { soci.en.11.1.1905.2021 }\end{array}$ & $\begin{array}{l}\text { As the higher education sector is more competitive and } \\
\text { globalized, service quality and student satisfaction are } \\
\text { increasingly essential and attract more attention. However, } \\
\text { research on this topic usually employed general service models } \\
\text { applied for the higher education context. This paper investigates } \\
\text { the service auality in hioher education hy combining the }\end{array}$ \\
\hline Received: June $01^{\text {st }}, 2021$ & HEdPERF model and the popular two-dimensional service \\
\hline Revised: June $16^{\text {th }}, 2021$ & quality model to link the general and context-focused \\
\hline Accepted: June $19^{\text {th }}, 2021$ & $\begin{array}{l}\text { perspective. Data were obtained from } 335 \text { respondents who are } \\
\text { students in Vietnamese universities. Findings indicate the effects } \\
\text { of functional and technical service quality on student satisfaction } \\
\text { and determine each HEdPERF dimension's relationships on the } \\
\text { two dimensions of service quality. This study contributes to }\end{array}$ \\
\hline Keywords: & understanding the path from service performance in the higher \\
\hline $\begin{array}{l}\text { HEdPERF; higher education; } \\
\text { service quality; student } \\
\text { satisfaction; Vietnam }\end{array}$ & $\begin{array}{l}\text { education sector, service quality dimensions, and satisfaction. } \\
\text { This also provides suggestions for Vietnamese universities in } \\
\text { improving their performance and services. }\end{array}$ \\
\hline
\end{tabular}

\section{Introduction}

Students have a variety of preferences in everyday life (Akkerman \& Bakker, 2019). Students have developed a variety of preferences in choices both within and outside the school realm since kindergarten. Since not all of these passions can be pursued simultaneously, students actively compete for their time (Hofer, 2010). Based on the incentive context offered for individual engagements, the method of comparing preferences and choosing what to spend time on is likely intuitive. When faced with a high-stakes decision, such as deciding on a higher education program, priorities can be evaluated more clearly (Vulperhorst, Wessels, Bakker, \& Akkerman, 2018).

Service quality is described by Parasuraman, Zeithaml, and Berry (1988, p. 15) as "a comparison of expectations with perceptions of performance resulting to a type of attitude, related but not identical to satisfaction." Several longitudinal studies were conducted on this topic for the explanation. For instance, the expectancy-disconfirmation principle underpins the service quality definition, closely related to customer satisfaction (Parasuraman, Zeithaml, \& Berry, 1985). Grönroos (1982) and Tran and Le (2020) illustrated that service quality affects the importance of an experience, the quality of a partnership, and the likelihood of purchasing. Despite the significant consequences for administrators, researchers, customers, service efficiency, experience meaning, interaction quality, and action motives, they are all poorly understood in current literature. For instance, if a client has had a positive encounter with a 
service provider, they are more likely to continue doing business with them. Customers who receive inadequate treatment, on the other hand, are more likely to turn to another service provider (Bhattacherjee, 2001). Therefore, customers' views of service quality have become a priority for service organizations because it lets them build plans that contribute to customer loyalty (Saravanan \& Rao, 2007). With intensified competition in the service sector, the definition of service quality has become more relevant.

The value of providing a good brand origination for customers to continue offering superior results has been indicated in the literature (Wong \& Merrilees, 2008). In the context of higher education services, brands have long been viewed as a barometer of excellence (Judson, Aurand, Gorchels, \& Gordon, 2008). A good university brand will lead to an outstanding reputation image (Palacio, Meneses, \& Pérez, 2002), allowing the university to consider itself as a top, leading, or world-class institution (Belanger, Mount, \& Wilson, 2002). So far, the assumption that customer idea is essential to students and that a marketing discourse is acceptable to their interests. As a result, university educators must encourage high-quality programs in order to stand out and perform effectively. The distinct aspect resulting in better facilities can be paid greater attention to core university capacities (Ong \& Nankervis, 2012). According to Abdullah (2006a), customer satisfaction is a critical element of university performance and can enhance perceived service efficiency. As a result, students are considered primary consumers of higher education institutions, and student retention becomes a critical factor for educational institutions in recruiting new students (Thomas \& Galambos, 2004). As a result of this phenomenon, universities have been challenged to offer their students the best service to gain competitive advantages. Higher education institutions should comprehend the mechanism of generating student satisfaction and develop reliable methods for measuring satisfaction (Alves \& Raposo, 2009). The term "customer" in higher education encompasses not only students but also administrative staff, lecturers, government agencies, communities, and society at large, implying that universities must meet a wide variety of needs (Abdullah, 2006b). Ali and Raza (2017), Brady and Cronin (2001), Chen (2008), and Nunkoo, Teeroovengadum, Thomas, and Leonard (2017) have shown that service quality has a strong beneficial effect on consumer loyalty. In recent years, Asian universities are working to increase student satisfaction and retention by studying quality problems and maintaining current and planned service levels (Yeo \& Li, 2014).

Scholars have made a significant effort to conduct several studies to determine how various service quality instruments are used in various industries (Brady, Cronin, \& Brand, 2002). The common tools used to measure the applicable efficiencies include SERVQUAL, SERVPERF, and a combined SER-IMPERF scale (Anvari Rostami, Torabi Goudarzi, \& Mohammadloo, 2005). The SERVQUAL scale is used to evaluate the service quality in tertiary education. This method will help education institutions understand their status quo of service quality, for example, whether or not it misses the traditional aspects of service quality such as tangibles, reliability, assurance, responsiveness, and empathy (Zeshan, Afridi, \& Khan, 2010). Researchers have also developed various models for assessing service quality. In this study, the HEdPERF model is combined with the standard two-dimensional service quality model to link the general and context-focused perspectives to ascertain the impact of technical and functional service quality on student satisfaction, the relationships between HEdPERF and two service quality dimensions. This research integrates HEdPERF with the traditional two-dimensional model of service quality to merge general and context-based viewpoints, detect the effects on student satisfaction of technical and functional service quality, and the relations between HEdPERF and two dimensions of service quality. 


\section{Theoretical background}

Tran and Le (2020) found that the quality of service affects the importance of customer experience, the strength of a partnership, and the likelihood of making a purchase. Despite the critical implications for management, academics, and customers, service efficiency, experience meaning, interaction quality, and action motives are all poorly understood in current literature. In the context of higher education, service quality is increasingly essential in affecting student success. However, the assessment is focused on the experiences of different state officials who have worked in higher education institutions. According to Jancey and Burns (2013), students are the most critical stakeholder in higher education institutions, and their interactions with various programs are based on their college years. In the ASIAN (The Association of Southeast Asian Nations) region, there were 11 standards used in the ASEAN region to determine the region's educational standard (ASEAN University Network-Quality Assurance, stand for AUNQA). The assessment requirements for quality education came to a halt well before the university, which is perceived to have fulfilled its objectives. Simultaneously, the standard aims to function as a tool for university self-assessment and educate authorities about the fundamental standards of education, as there is no objective evaluation of enhanced measures of quality based on rating agencies' evaluations. Additionally, Nguyen, Nguyen, and Nguyen (2019) showed that researchers and education institution managers in Vietnam currently retain the view that education is a service and students are consumers. As a result, administrators increasingly appreciated education when evaluating students' service efficiency at a university.

The development of many methods has arisen from an effort to establish an assessment criterion independent of any specific service context. SERVPERF (Parasuraman et al., 1985) holds just the impressions of service quality, while SERVQUAL (Cronin \& Taylor, 1992) operationalizes service quality by contrasting the perceptions of the service obtained with expectations. On the other hand, E.P. scale (Abdullah, 2006a) measures the difference between perceived output and the desired level of a function, rather than measuring consumer preferences. Various experiments using these scales have shown that problems are arising from both the logical and analytical components as well as the method dimension. In light of this, Abdullah (2006c) suggested HEdPERF (Higher Education PERFormance-only), a recent and more detailed performance-based measuring scale aimed at capturing the genuine determinants of service quality in the higher education sector. The SERVPERF instrument and the combined HEdPERF-SERVPERF as moderating scale are compared to the more concise HEdPERF scale's abilities. The aim is to evaluate the instrument with the superior measuring capacity in terms of unidimensionality, reliability, validity, and explained variation in service efficiency by determining each instrument's relative strengths and limitations. HEdPERF model is formed and developed based on the limitations of the existing service quality scales to overcome the shortcomings and provide a multidimensional service quality measurement. The reasons exist in reality; the debate over how to quantify the standard of service still has drawbacks. There are still valid concerns and solutions on each side of this discussion, as the argument over the differences (SERVQUAL), perception-only (SERVPERF), and E.P. approach to service quality is unanswered. SERVQUAL, SERVPERF and the E.P. are intended for general service quality measurements with cross-industry use. Additionally, quality initiatives are being stepped up in higher education, emphasizing the responsibility for education.

Therefore, Abdullah (2006b) identified essential service efficiency variables or determinants in measuring service quality in higher education. Factor analysis was used to determine the dimensional structure of the level of service in the higher education sectors. Specifically, the research finding resulted: Non- academic aspects, academic aspects, access, 
reputation, program issues, and understanding are significant factors. In detail, meanwhile, nonuniversity aspects consist of vital things for the students to fulfill their studies responsibilities and concern tasks performed by non-academic personnel or academic aspects, all things related to university's obligations, communication facility, reachability and item's availability are factors of access. Reputation is charged with objects showing the relevance of presenting a professional picture of higher educational institutions. Program issues are the value of providing comprehensive and trustworthy academic programs with scalable structures and programs understanding, including issues concerning the awareness of students' basic needs in terms of advice and health services.

\section{Model and hypotheses}

The traditional two-dimensional model of service quality reflected student perceptions of service quality; satisfaction can be more valuable and significant for higher education as a business and customer relationship management. Grönroos (1994) characterized the basic service quality theory of technical and functional service quality. Service performance measures technical service quality, while functional service quality is correlated with service delivery perception.

\section{Table 1}

Definitions of factors

\begin{tabular}{|l|l|}
\hline Non-Academic Aspects & $\begin{array}{l}\text { The component that pertains to the administrative office's tasks is in } \\
\text { charge of meeting the demands of university students }\end{array}$ \\
\hline Academic Aspects & $\begin{array}{l}\text { The academic refers to the main tasks and functions of academic } \\
\text { staffs, which are transmitting of knowledge through research }\end{array}$ \\
\hline Access & $\begin{array}{l}\text { Access is in relation to the ease of contact, reachability, and } \\
\text { availability of items }\end{array}$ \\
\hline Reputation & $\begin{array}{l}\text { This view can be seen as the image of the institution perceived by } \\
\text { students }\end{array}$ \\
\hline Program Issues & $\begin{array}{l}\text { This component concentrates on the importance of specialization } \\
\text { offered by educational institutions }\end{array}$ \\
\hline Understanding & $\begin{array}{l}\text { This attribute is about the service's capacity to understand the } \\
\text { students'specific needs (e.g., counseling, health services) }\end{array}$ \\
\hline
\end{tabular}

Source: Abdullah (2006c)

Based on theoretical reviews, preliminary hypotheses are conducted for testing the relationships between measurement determinants in the HEdPERF model and two factors in the traditional model for service quality measurement. Researchers as Cronin and Taylor (1994), Grönroos (1994), and Parasuraman and Zeithaml (1985) believed that the consistency of services has a beneficial effect on satisfaction, which is considered with the relationship between service quality and behavioral intentions to be a good mediator. It provides convincing proof of the suggestion that service quality is precedent to satisfaction (Cronin, Brady, \& Hult, 2000). 


\section{Table 2}

List of hypotheses

\begin{tabular}{|c|l|}
\hline Hypothesis & \\
\hline H1 & Non-Academic aspects affect functional service quality \\
\hline H2 & Academic aspects affect functional service quality \\
\hline H3 & Access affects functional service quality \\
\hline H4 & Reputation affects functional service quality \\
\hline H5 & Program issues affect functional service quality \\
\hline H6 & Understanding affects functional service quality \\
\hline H7 & Non-Academic aspects technical service quality \\
\hline H8 & Academic aspects technical service quality \\
\hline H9 & Access affects technical service quality \\
\hline H10 & Reputation affects technical service quality \\
\hline H11 & Program issues affect technical service quality \\
\hline H12 & Understanding affects technical service quality \\
\hline H13 & $\begin{array}{l}\text { There is a link between student's perceived functional service quality and student } \\
\text { satisfaction }\end{array}$ \\
\hline There is a connection between student's perceived technical service quality and \\
student satisfaction
\end{tabular}

Source: Developed by the authors

The research model in question is made up of two pieces in general. The first one, in particular, looks at how each factor affects technical and functional service quality. In fact, the second segment aims to uncover the links between two types of service quality and student satisfaction in Vietnamese institutions.

Figure 1 shows the model of the various hypothesized partnerships. In this analysis, which is debated in subsequent pages, a model with latent buildings and hypothesized relationships is analyzed. 


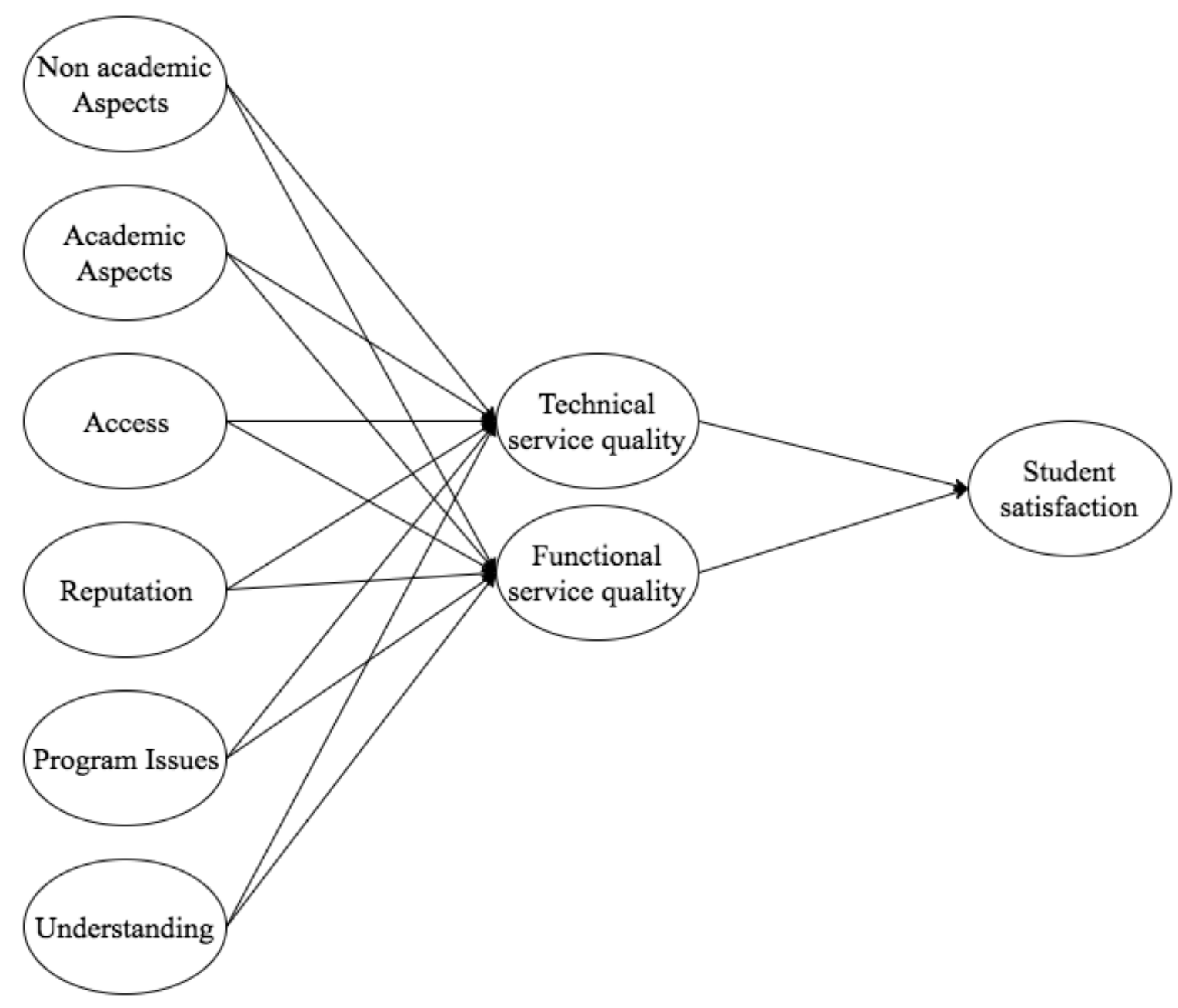

Figure 1. The current research framework

\section{Research design}

Data were obtained from 335 students in Vietnamese universities by collecting primary and secondary data, including questionnaires (survey by online form and paper form) via Facebook and Gmail for primary data. The research was conducted by combining the HEdPERF model and the popular two-dimensional service quality model to link the general and contextfocused perspective.

Using the quantitative method for testing the 06 variables of HEdPERF model impact on 02 aspects: Technical and functional service quality. To make a pre-determined hypotheses testing and meet the paper demand, quantitative approach to figure out possibly cause-effect relationship.

The research got the valid data at 335 respondents who are Bachelor (46\%) and Master degree (44\%). Ph.D./Doctor degree is made up of 10\% from 03 types of universities: Public, private, and international universities in Vietnam with the most part are female (59\%), the complete measuring scale with a mixture of 42 variables observed from 09 parameters fulfills convergent validity, discriminative validity and composite reliability requirements before confirmatory factor analysis (CFA) was conducted. 


\section{Table 3}

Measurement scale

\begin{tabular}{|c|c|c|}
\hline Variables & Item No. & Instrument \\
\hline \multirow[t]{10}{*}{$\begin{array}{l}\text { Non-Academic } \\
\text { aspects }\end{array}$} & NACA1 & $\begin{array}{l}\text { When I have a problem, administrative staffs show a sincere } \\
\text { interest in solving it }\end{array}$ \\
\hline & NACA2 & Administrative staffs pay warm attention \\
\hline & NACA3 & Inquiries are handled efficiently \\
\hline & NACA4 & Administration offices keep accurate and retrievable records \\
\hline & NACA5 & $\begin{array}{l}\text { When the administrative staffs promise to complete a task } \\
\text { punctually, they do so }\end{array}$ \\
\hline & NACA6 & $\begin{array}{l}\text { Administrative staffs show a positive work attitude towards } \\
\text { students }\end{array}$ \\
\hline & NACA7 & Administrative staffs are good at catching up with students \\
\hline & NACA8 & Administrative staffs have good knowledge of the systems \\
\hline & NACA9 & Students are treated equally by the staffs \\
\hline & NAC10 & $\begin{array}{l}\text { The staffs respect the terms of confidentiality when I disclose } \\
\text { information to them }\end{array}$ \\
\hline \multirow[t]{9}{*}{$\begin{array}{l}\text { Academic } \\
\text { Aspects }\end{array}$} & ACA1 & $\begin{array}{l}\text { When I have a problem, lecturers show a sincere interest in } \\
\text { solving it }\end{array}$ \\
\hline & ACA2 & Lecturers deal in a courteous manner \\
\hline & ACA3 & $\begin{array}{l}\text { Lecturers have the knowledge to answer my questions relating } \\
\text { to the course content }\end{array}$ \\
\hline & ACA4 & Lecturers show a positive attitude towards students \\
\hline & ACA5 & Lecturers communicate well in the classroom \\
\hline & ACA6 & Lecturers provide advice and instructions about my progress \\
\hline & ACA7 & Lecturers are highly trained in their respective field \\
\hline & ACA8 & The hand-outs are provided adequately by the lecturers \\
\hline & ACA9 & The documentations are provided adequately by the lecturers \\
\hline \multirow[t]{4}{*}{ Access } & ACCE1 & $\begin{array}{l}\text { Academic staffs are willing to respond to my request for } \\
\text { assistance }\end{array}$ \\
\hline & ACCE2 & Academics staffs allocate sufficient time for consultation \\
\hline & ACCE3 & The staffs ensure that they are easily contacted \\
\hline & ACCE4 & Academic staff are known to respond to my request \\
\hline \multirow[t]{3}{*}{ Program Issues } & PROG1 & The university runs excellent quality programs \\
\hline & PROG2 & $\begin{array}{l}\text { The university offers a wide range of program with various } \\
\text { specializations }\end{array}$ \\
\hline & PROG3 & The university offers a curriculum with a flexible structure \\
\hline
\end{tabular}




\begin{tabular}{|c|c|c|}
\hline Variables & Item No. & Instrument \\
\hline & PROG4 & Course content is relevant to the future/current job of students \\
\hline \multirow[t]{3}{*}{ Reputation } & REPU1 & The university has a professional image \\
\hline & REPU2 & The academic program run by the university is renowned \\
\hline & REPU3 & The university's graduates are easily employable \\
\hline \multirow[t]{4}{*}{ Understanding } & UNDER1 & Availability of lecturers to guide and advise students \\
\hline & UNDER2 & Availability of adequate health service facilities \\
\hline & UNDER3 & The university operates an excellent counseling service \\
\hline & UNDER4 & $\begin{array}{l}\text { The university has favorable ambient conditions (ventilation, } \\
\text { noise, odor, etc.) prevailing within the campus }\end{array}$ \\
\hline \multirow[t]{5}{*}{$\begin{array}{l}\text { Functional } \\
\text { Service Quality }\end{array}$} & FSQ1 & The university provided good service right from the beginning \\
\hline & FSQ2 & The lecturers and administrative staffs are courteous \\
\hline & FSQ3 & $\begin{array}{l}\text { The lecturers and administrative staffs are always willing to } \\
\text { assist }\end{array}$ \\
\hline & FSQ4 & $\begin{array}{l}\text { The lecturers and administrative staffs always give me } \\
\text { efficient/prompt service dealing with complaints }\end{array}$ \\
\hline & FSQ5 & $\begin{array}{l}\text { Administrative procedures are clear and well structured so that } \\
\text { service delivery times are minimum }\end{array}$ \\
\hline \multirow[t]{5}{*}{$\begin{array}{l}\text { Technical } \\
\text { Service Quality }\end{array}$} & TSQ1 & All knowledge I gain from my university is completely valuable \\
\hline & TSQ2 & $\begin{array}{l}\text { The university helps students acquire adequate knowledge and } \\
\text { skills to perform a future job, increase in knowledge, abilities, } \\
\text { and skills }\end{array}$ \\
\hline & TSQ3 & $\begin{array}{l}\text { The university develops students' problem-solving skills with } \\
\text { respect to their field of study }\end{array}$ \\
\hline & TSQ4 & The university has a high level of employment \\
\hline & TSQ5 & The university increases in self-confidence of students \\
\hline \multirow[t]{5}{*}{$\begin{array}{l}\text { Student } \\
\text { satisfaction }\end{array}$} & SAT1 & I am satisfied with my decision to register at this university \\
\hline & SAT2 & My choice to choose this university was a wise one \\
\hline & SAT3 & $\begin{array}{l}\text { I think I did the right thing when I chose to study at this } \\
\text { university }\end{array}$ \\
\hline & SAT4 & $\begin{array}{l}\text { I feel that my experience with this university has been } \\
\text { enjoyable }\end{array}$ \\
\hline & SAT5 & Overall, I am satisfied with this university \\
\hline
\end{tabular}

Source: Adapted from Abdullah (2006b), Grönroos (1994) 


\section{Results}

Composite Reliability coefficient (CR) and convergent validity were used to test each construct with the Average Variance Extracted (AVE) score for the assessment of converging validity. As results showed from Table 4 while (CR) resulted from a range from 0.799 to $0.899>$ 0.7 (recommended minimum reliability value), showed they have internal consistency, the result of Average Variance Explained (AVE) figured out in a range between $50.6 \%$ and $62.4 \%$, which is higher for suggesting the value of $0.50(50 \%)$. As a consequence, the research also enables to make sure the scale's reliability.

Fornell and Larcker (1981) illustrated in their procedure that the requirement for validity in discriminant reliability testing for various constructs is if Average Variance Explained (AVE) score of constructs was greater than their shared variance - the squared correlation between them. Therefore, Table 4 shows that the mutual variance among each construct pair is less than that of the AVE ratings of the relevant metrics, meaning that all constructs are discriminating invalidity and that the different constructions can be employed confidently.

\section{Table 4}

An assessment of discriminant validity (variance extracted and shared variance) ${ }^{\mathrm{a}}$

\begin{tabular}{|c|c|c|c|c|c|c|c|c|c|c|}
\hline Construct & $\begin{array}{c}\text { Variance } \\
\text { extracted } \\
(\text { AVE) }\end{array}$ & $\begin{array}{l}\text { Composite } \\
\text { reliability }\end{array}$ & $\begin{array}{c}\text { Functional } \\
\text { Service } \\
\text { Quality }\end{array}$ & $\begin{array}{l}\text { Unders } \\
\text { tanding }\end{array}$ & Reputation & $\begin{array}{c}\text { Acces } \\
\mathbf{S}\end{array}$ & $\begin{array}{l}\text { Program } \\
\text { Issues }\end{array}$ & $\begin{array}{c}\text { Technical } \\
\text { Service } \\
\text { Quality }\end{array}$ & $\begin{array}{c}\text { Student } \\
\text { Satisfaction }\end{array}$ & $\begin{array}{l}\text { Academic } \\
\text { aspects }\end{array}$ \\
\hline $\begin{array}{l}\text { Functional } \\
\text { Service } \\
\text { Quality }\end{array}$ & 0.57 & 0.80 & & & & & & & & \\
\hline $\begin{array}{l}\text { Understandin } \\
\mathrm{g}\end{array}$ & 0.6 & 0.81 & 0.2 & & & & & & & \\
\hline Reputation & 0.62 & 0.83 & 0.11 & 0.09 & & & & & & \\
\hline Access & 0.55 & 0.83 & 0.21 & 0.27 & 0.09 & & & & & \\
\hline $\begin{array}{l}\text { Program } \\
\text { Issues }\end{array}$ & 0.6 & 0.86 & 0.23 & 0.23 & 0.1 & 0.18 & & & & \\
\hline $\begin{array}{l}\text { Technical } \\
\text { Service } \\
\text { Quality }\end{array}$ & 0.57 & 0.87 & 0.4 & 0.21 & 0.13 & 0.18 & 0.16 & & & \\
\hline $\begin{array}{l}\text { Student } \\
\text { Satisfaction } \\
\end{array}$ & 0.51 & 0.84 & 0.38 & 0.13 & 0.09 & 0.11 & 0.09 & 0.42 & & \\
\hline $\begin{array}{l}\text { Academic } \\
\text { aspects }\end{array}$ & 0.5 & 0.88 & 0.11 & 0.07 & 0.01 & 0.02 & 0.07 & 0.04 & 0.04 & \\
\hline $\begin{array}{l}\text { Non- } \\
\text { Academic } \\
\text { Aspects }\end{array}$ & 0.53 & 0.90 & 0.1 & 0.02 & 0.01 & 0.06 & 0.04 & 0.1 & 0.03 & 0.02 \\
\hline
\end{tabular}

Note: the constructs' shared variances are shown in the lower half of the triangular matrix

Source: Developed by the authors

The Structural Equation Model (SEM) findings with a measuring model show that the model is 790 degrees of freedom. Although the amount of the Chi-square is adjusted according to the freedom level, considering the fact it has $\mathrm{p}=1.000$ (Chi-Square $=968.763$ ), in addition, it is $\mathrm{CMIN} / \mathrm{df}=1.226$ (condition > 2.00). Furthermore, there are also appropriate other parameters, including GFI $=.8874$; CFI $=.969$; TLI $=.966$ and RMSEA $=.028$ (request $<.0800$ ). This model should then be considered as being fully satisfactory for all data gathered by respondents. 


\section{Table 5}

Results of the structural model

\begin{tabular}{|c|l|c|c|c|}
\hline \multicolumn{2}{|c|}{ Hypotheses } & Coefficient & p-value & Result \\
\hline H1 & Non-Academic aspects $\rightarrow$ Functional service quality & 0.159 & 0.007 & Supported \\
\hline H2 & Academic aspects $\rightarrow$ Functional service quality & 0.005 & 0.176 & Supported \\
\hline H3 & Access $\rightarrow$ Functional service quality & 0.184 & 0.017 & Supported \\
\hline H4 & Reputation $\rightarrow$ Functional service quality & 0.159 & 0.014 & Supported \\
\hline H5 & Program issue $\rightarrow$ Functional service quality & 0.197 & 0.007 & Supported \\
\hline H6 & Understanding $\rightarrow$ Functional service quality & 0.159 & 0.051 & Rejected \\
\hline H7 & Non-Academic aspects $\rightarrow$ Technical service quality & 0.184 & 0.002 & Supported \\
\hline H8 & Academic aspects $\rightarrow$ Technical service quality & 0.064 & 0.284 & Rejected \\
\hline H9 & Access $\rightarrow$ Technical service quality & 0.152 & 0.041 & Supported \\
\hline H10 & Reputation $\rightarrow$ Technical service quality & 0.193 & 0.002 & Supported \\
\hline H11 & Program issue $\rightarrow$ Technical service quality & 0.112 & 0.111 & Rejected \\
\hline H12 & Understanding $\rightarrow$ Technical service quality & 0.237 & 0.003 & Supported \\
\hline H13 & Functional service quality $\rightarrow$ Student satisfaction & 0.35 & 0.000 & Supported \\
\hline H14 & Technical service quality $\rightarrow$ Student satisfaction & 0.459 & 0.000 & Supported \\
\hline
\end{tabular}

Source: Developed by the authors

As illustrated, all correlations hypothesized by the Structural equation model are shown (SEM) in Table 5. The relationship between Understanding and Functional Service Quality, Academic Aspects and Technical Service Quality, Program Issues and Technical Service Quality have a p-value $=0.051>5 \%, 0.284>5 \%, 0.111>5 \%$. At the reliability level, they are absolutely meaningless at $\mathrm{p}>.05,95$ percent.

As a result, Non-Academic aspects were initially found to impact significantly the standard of usable operation $(\beta=0.159, \mathrm{p}<0.05)$, which supports H1. Furthermore, the result indicates to support $\mathrm{H} 2$ that academic factors affect the standard of functional service $(\beta=0.005$, $\mathrm{p}<0.05)$. Another aspect that certainly influences the consistency of the usable service ( $\beta=$ $0.184, \mathrm{p}<0.05)$ is accessed; thus, H3 is assisted. The reputation and functional service quality relationship $(\beta=0.159, \mathrm{p}<0.05)$ is consequently registered and therefore also sponsored by $\mathrm{H} 4$. The next step is to analyze the linkage between program issues and consistency of functional services $(\beta=0.197, \mathrm{p}<0.05), \mathrm{H} 5$ is approved. 


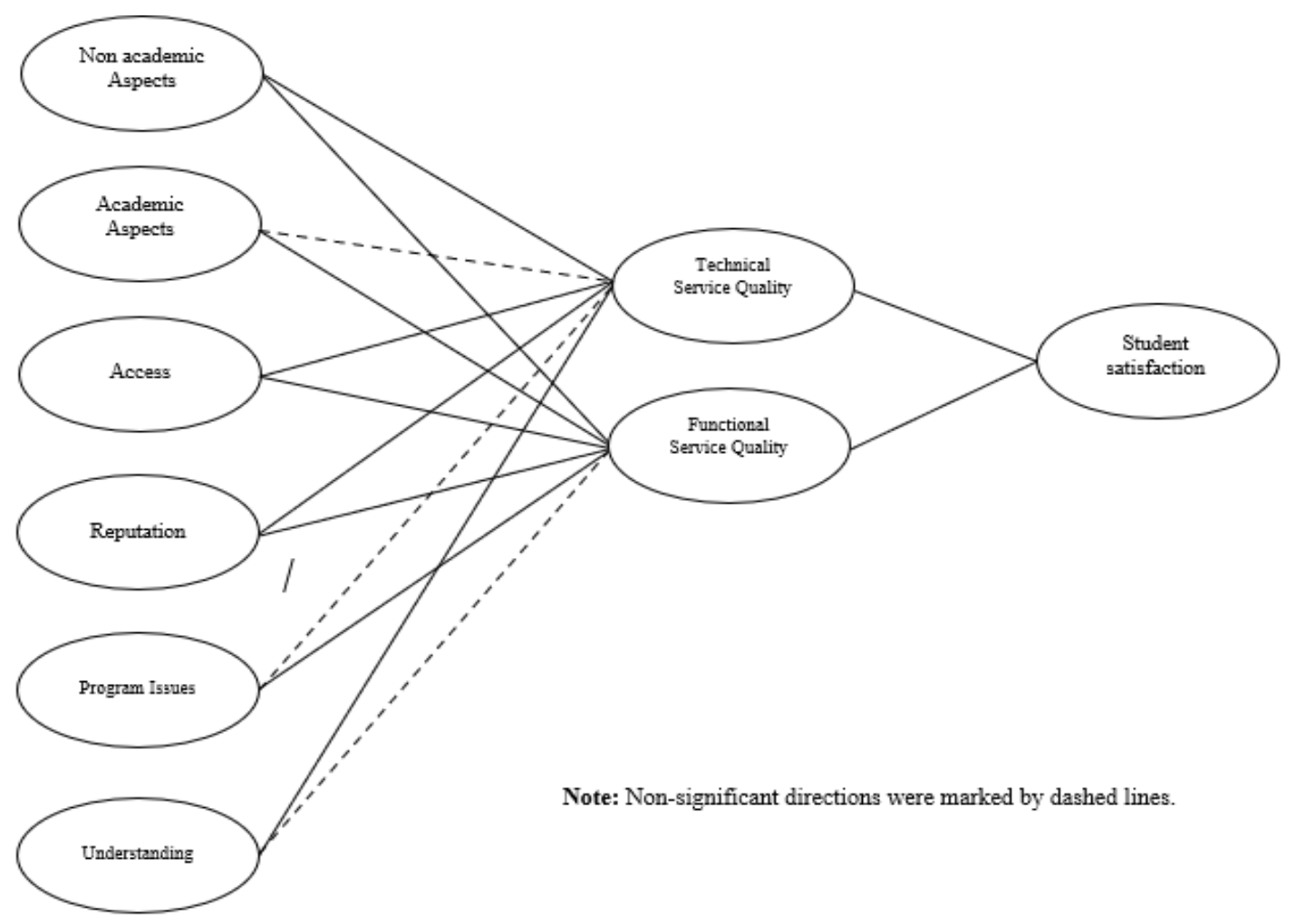

Figure 2. The final framework

Although other ties are still meaningful for statistical importance, three hypotheses (H6, $\mathrm{H} 8, \mathrm{H} 11)$ are denied. In comparison, $\mathrm{H} 7$ is endorsed because non-Academic factors greatly influence the standard of technical service $(\beta=0.184, p<0.05)$. The relationship between access and technical service efficiency $(\beta=0.152, p<0.05)$ was thus verified as critical (H9). Furthermore, Reputation also affects the consistency of technical service $(\beta=0.193, p<0.05)$, which ensures the complete support for H10 is given. Comprising technical service standard with understanding $(\beta=0.237, p<0.05)$, confirmation of H12. Functional service efficiency in favor of H13 can be shown to have important impacts on student satisfaction $(\beta=0.35, \mathrm{p}<0.05)$. Later, it is evident that professional service efficiency is unquestionably linked to student enjoyment $(=0.459, \mathrm{p}<0.05)$, thus endorsing H14.

To help explain the relative significance of each construct, the overall effects of each construct on the other constructs in the model were also analyzed for both direct and indirect effects, and the findings are shown in Table 5.

\section{Conclusion}

\subsection{Contribution}

Through conducting research into the effects of service quality variables at Vietnam's universities, this research not only confirms the existence of determinants (non-academic sides, academic traits, admission, reputation, and program issues all influence functional service quality), but it also shows that functional service quality is unaffected. In other words, there is no connection between the dimension and the growth of service quality, although it continues to play a significant role in service quality prosperity. Furthermore, three factors affect the level of functional service: access, reputation, and non-academic factors. By contrast, the findings are consistent with previous research on the impact of two types of efficiency, namely technical and functional quality of service, on satisfaction. That is, all measurements derived from HEdPERF 
(Abdullah, 2005) may have an effect on functional and technical service efficiency at various levels. The important stated that "non-academic considerations" are the primary determinants of service efficiency, implying that administrative staff plays a critical role in extending the service provided. In terms of methodological engagement, the study's final findings can be seen as a significant contributor to creating a wide spectrum of additional consumer (student) insight. There is an agreement between the findings and prior research on the effects of two types of service quality, specifically technical and functional service quality, on satisfaction (Teo and Soutar, 2012). This study delicates to improve this measuring scale to become more trustworthy and legitimate, which is utilized for service quality assessment in universities, using a thorough and developmental method. Within this study, based on the HEdPERF scale, there is a combination of six components and a total of 42 items.

Furthermore, the accomplishment of this research is that many criteria of service quality (based on the HEdPERF scale) are completely integrated into the study model. Meanwhile, the prior study has not yet explored and accepted service quality ideas to investigate which the most important variables are.

In reality, hypotheses involving the combination of comprehension and practical service quality, program issues and technical service quality, theoretical aspects, and technical service quality are not accepted as plausible conclusions. As a result, management staff plays an important role in enhancing technical assistance and functional operation. In this respect, university administration should be adaptable to prioritize discovering and understanding the students' fascination at a local level through the skills and capacities gained after entering their university. To be more specific, one of the defining characteristics of educational institutions' excellence is the enhancement of technological and practical levels of operation, resulting in a significant increase in customer satisfaction. Skilled service quality has a greater effect on student satisfaction than functional service quality, while functional service quality contributes to obsession with high contrast service sectors.

\subsection{Recommendation}

As a result of these observations, non-academic staff's responsibilities, flexibility, and professional identification seem to be the most significant influences in improving service efficiency. Universities in Vietnam should ensure that students have regular access to faculty members by email, phone, or in person. Professional and practical service levels in Vietnamese tertiary education attributes can be improved due to these rules, resulting in higher student satisfaction.

As a result, this viewpoint demonstrates that Vietnamese students may target Vietnam universities' professional image and service persuasion in the future. Educational agencies would continue to update and compare themselves to other organizations in this sector as a benchmark. This study's implications are limited to the higher education sector, so its implications are limited to this field, despite some dominance in understanding the relationship between two terms of service quality. Furthermore, the data gathered at Vietnam National University (Ho Chi Minh City) does not completely reflect the viewpoint in this report. Further studies by Vietnamese universities would cover new dimensions for determining service quality. Future studies will concentrate on elucidating the long history of two forms of quality service, as well as their effect on student satisfaction and actions. 


\section{References}

Abdullah, F. (2005). HEdPERF versus SERVPERF: The quest for ideal measuring instrument of service quality in higher education sector. Quality Assurance in Education, 13(4), 305-328. doi:10.1108/09684880510626584

Abdullah, F. (2006a). Measuring service quality in higher education: HEdPERF versus SERVPERF. Marketing Intelligence and Planning, 24(1), 31-47. doi:10.1108/02634500610641543

Abdullah, F. (2006b). Measuring service quality in higher education: Three instruments compared. International Journal of Research and Method in Education, 29(1), 71-89. doi:10.1080/01406720500537445

Abdullah, F. (2006c). The development of HEdPERF: A new measuring instrument of service quality for the higher education sector. International Journal of Consumer Studies, 30(6), 569-581. doi:10.1111/j.1470-6431.2005.00480.x

Akkerman, S. F., \& Bakker, A. (2019). Persons pursuing multiple objects of interest in multiple contexts. European Journal of Psychology of Education, 34(1), 1-24.

Ali, M., \& Raza, S. A. (2017). Service quality perception and customer satisfaction in Islamic banks of Pakistan: The modified SERVQUAL model. Total Quality Management \& Business Excellence, 28(5/6), 559-577.

Alves, H., \& Raposo, M. (2009). The measurement of the construct satisfaction in higher education. The Service Industries Journal, 29(2), 203-218.

Anvari Rostami, E. A., Torabi Goudarzi, M., \& Mohammadloo, A. (2005). Comparison of banking services quality from viewpoints of customers and staff. Modarres Human Sciences, 4(3), 23-34.

Belanger, C., Mount, J., \& Wilson, M. (2002). Institutional image and retention. Tertiary Education \& Management, 8(3), 217-230.

Bhattacherjee, A. (2001). An empirical analysis of the antecedents of electronic commerce service continuance. Decision Support Systems, 32(2), 201-214.

Brady, M. K., \& Cronin, J. J. Jr. (2001). Some new thoughts on conceptualizing perceived service quality: A hierarchical approach. Journal of Marketing, 65(3), 34-49.

Brady, M. K., Cronin, J. J. Jr., \& Brand, R. R. (2002). Performance-only measurement of service quality: A replication and extension. Journal of Business Research, 55(1), 17-31.

Chen, C. F. (2008). Investigating structural relationships between service quality, perceived value, satisfaction, and behavioral intentions for air passengers: Evidence from Taiwan. Transportation Research Part A: Policy and Practice, 42(4), 709-717.

Cronin, J. J. Jr., Brady, M. K., \& Hult, G. T. M. (2000). Assessing the effects of quality, value, and customer satisfaction on consumer behavioral intentions in service environments. Journal of Retailing, 76(2), 193-218.

Cronin, J. J. Jr., \& Taylor, S. A. (1992). Measuring service quality: A reexamination and extension. Journal of Marketing, 56(3), 55-68.

Cronin, J. J., \& Taylor, S. A. (1994). SERVPERF versus SERVQUAL: Reconciling Performance-based and perceptions-minus-expectations measurement of service quality. Journal of Marketing, 58(1), 125-131. doi:10.2307/1252256 
Fornell, C., \& Larcker, D. F. (1981). Evaluating structural equation models with unobservable variables and measurement error. Journal of Marketing Research, 18(1), 39-50. doi:10.1177/002224378101800104

Grönroos, C. (1982). An applied service marketing theory. European Journal of Marketing, 16(7), 30-41.

Grönroos, C. (1994). From scientific management to service management: A management perspective for the age of service competition. International Journal of Service Industry Management, 5(1), 5-20.

Hofer, M. (2010). Adolescents' development of individual interests: A product of multiple goal regulation? Educational Psychologist, 45(3), 149-166.

Jancey, J., \& Burns, S. (2013). Institutional factors and the postgraduate student experience. Quality Assurance in Education, 21(3), 311-322.

Judson, K. M., Aurand, T. W., Gorchels, L., \& Gordon, G. L. (2008). Building a university brand from within: University administrators' perspectives of internal branding. Services Marketing Quarterly, 30(1), 54-68.

Nguyen, H. T., Nguyen, T. D., \& Nguyen, T. N. (2019). Beyond traditional probabilistic methods in econometrics. In V. Kreinovich, T. N. Nguyen, T. D. Nguyen \& T. V. Dang (Eds.), Studies in computational intelligence, (pp. 3-21). Paso, TX: Springer. doi:10.1007/978-3-030-04200-4_1

Nunkoo, R., Teeroovengadum, V., Thomas, P., \& Leonard, L. (2017). Integrating service quality as a second-order factor in a customer satisfaction and loyalty model. International Journal of Contemporary Hospitality Management, 29(12), 2978-3005.

Ong, W. M., \& Nankervis, A. (2012). Service quality in higher education: Students' perceptions in Australia and Malaysia. Review of Integrative Business and Economics Research, 1(1), 277-290.

Palacio, A. B., Meneses, G. D., \& Pérez, P. J. P. (2002). The configuration of the University image and its relationship with the satisfaction of students. Journal of Educational Administration, 40(5), 486-505.

Parasuraman, A., \& Zeithaml, V. A. (1985). Problems and strategies in services marketing. Journal of Marketing, 49(2), 33-46.

Parasuraman, A., Zeithaml, V. A., \& Berry, L. L. (1985). A conceptual model of service quality and its implications for future research. Journal of Marketing, 49(4), 41-50.

Parasuraman, A., Zeithaml, V. A., \& Berry, L. (1988). SERVQUAL: A multiple-item scale for measuring consumer perceptions of service quality. 1988, 64(1), 12-40.

Saravanan, R., \& Rao, K. S. P. (2007). The impact of total quality service age on quality and operational performance: An empirical study. The TQM Magazine, 19(3), 197-205.

Thomas, E. H., \& Galambos, N. (2004). What satisfies students? Mining student-opinion data with regression and decision tree analysis. Research in Higher Education, 45(3), 251-269.

Tran, D. V., \& Le, T. N. M. (2020). Impact of service quality and perceived value on customer satisfaction and behavioral intentions: Evidence from convenience stores in Vietnam. The Journal of Asian Finance, Economics, and Business, 7(9), 517-526. 
Vulperhorst, J. P., Wessels, K. R., Bakker, A., \& Akkerman, S. F. (2018). How do STEMinterested students pursue multiple interests in their higher educational choice? International Journal of Science Education, 40(8), 828-846.

Wong, H. Y., \& Merrilees, B. (2008). The performance benefits of being brand-orientated. Journal of Product \& Brand Management, 17(6), 372-383.

Yeo, R. K., \& Li, J. (2014). Beyond SERVQUAL: The competitive forces of higher education in Singapore. Total Quality Management \& Business Excellence, 25(1/2), 95-123.

Zeshan, A., Afridi, T., \& Khan, S. M. (2010). Assessing service quality in business schools: Implications for improvement. Paper presented at 3rd International Conference on Assessing Quality in Higher Education, Lahore, Pakistan. 